\title{
Peter, Popes, Politics and More: the Apostle as Anchor
}

\author{
Roald Dijkstra
}

Et iam tenemus obsides

fidissimos huius spei,

hic nempe iam regnant duo

apostolorum principes;

alter uocator gentium;

alter, cathedram possidens

primam, recludit creditas

aeternitatis ianuas.

Already we hold most trusty sureties for this hope, for already there reign here the two chiefs of the apostles, the one he who called the Gentiles, while the other who occupies the foremost chair opens the gates of eternity which were committed to his keeping.

$$
\text { Prudentius, Peristephanon } 2.457^{-6} 4^{1}
$$

These verses are exclaimed by Rome's greatest "native" saint Laurentius in a poem by Prudentius. By doing so, the Roman saint testifies to the prominence of two Christians saints even more powerful and authoritative than himself: Peter and Paul. Prudentius makes Laurentius praise the apostle Peter in a most honourable way by referring to his extraordinary power: he holds the primary see and controls the doors of heaven. ${ }^{2}$ Both on earth and in the hereafter, Peter

1 I would like to thank Dr Erik Hermans for carefully reading my text. Thanks also go to all the contributors to the volume for sharing their thoughts on Peter, both in oral and written form. Text and translation of Prudentius: Thomson (1961 [1953]), slightly adapted.

2 See Dijkstra (2018) for Peter as the gatekeeper of heaven in early Christian poetry (and art). For more on Peristephanon 2 see Humphries in this volume; more on poetical petrine traditions is found in the contribution by Springer. 
is in charge. At the same time, Peter's authority in Rome (and that of Peter's self-proclaimed successors) is enforced by its connection to the Roman local saint Laurentius. These verses are just one example out of many that confirm Peter's prominent position within the religious, political and cultural Christian landscape of late antiquity.

Ever since the first century, Christians have engaged heated discussions about the nature and implications of Peter's special position in the Church (based mainly on Matt. 16.16-19). The historicity of the life of Peter as described in the books of the New Testament and some influential apocryphal texts (mainly the Acts of Peter) was hardly ever doubted in the period of our concern (1st-9th century CE). This is the reason why the reception of the apostle is much more important for the history of Christianity than the "historical Peter". ${ }^{3}$ The figure of Peter, i.e. the constructed image of a man equal to one of the apostles with this name, mentioned in the gospels but also in many other writings, images and traditions in (late) antiquity and the early middle ages, is the main subject of this book. ${ }^{4}$ In this contribution, the role of Peter as an anchor is explained, contextualised, and related to all the different other contributions this volume consists of.

\section{Anchoring the Apostle}

Nautical metaphors are not uncommon in the New Testament: Jesus' call of Peter and his brother Andrew - proclaiming to make them fishers of men (Matt. 4.19) is among the most famous examples of this biblical feature. It is another nautical, but not religiously charged, metaphor that is used as a starting point of the investigations towards the figure of Peter in this book: that of Anchoring Innovation. This concept, claiming that innovations have higher chances of success when they are successfully embedded - or anchored - in something known and familiar, has proven to be particularly insightful when applied to the role of Peter in the dynamics of late antiquity and the early middle ages. ${ }^{5}$

3 See for the historical Peter e.g. Hengel $\left(2007^{2}\right)$ or Wolter (2015). Clearly, there were dissenting voices that doubted the standard account of Peter's biography, but these critical opinions are only fragmentarily preserved. They were anchored in a "wrong" perception of the apostle, i.e. a version of his life that did not become accepted as legitimate by a majority of Christians and/or the clergy of the Catholic Church, cf. Burnet' contribution to this volume.

4 It is the explicit aim of this volume to surpass the artificial boundaries between (late) antiquity and the (early) middle ages. Nevertheless, the terms are used throughout this book as any other terms would be arbitrary as well.

5 See e.g. Dijkstra and Van Espelo (2017 and 2017a). Other examples of the use of the concept of Anchoring innovation related to power and sanctity can be found in this volume (see especially the contribution by Hekster), but also in the proceedings of the Anchoring Sanctity 
Shortly after the fisherman from Galilee had left his fishing boat, he became an anchor for many people across the Roman Empire. Traditions around Peter were so strong (i.e. anchored firmly), that already soon after his death people adhered to them and successfully employed them for diverging purposes. As a result, persons from all social strata and backgrounds could have recourse to the same figure: the apostle Peter, martyred in Rome. At the same time, firmly grounded traditions about Peter also restricted his use as an anchor in future times, in a process that Olivier Hekster has characterized as the "constraints of tradition". ${ }^{6}$ Not everything was possible. One example is the place of Peter's martyrdom. Whereas Peter's stay (and subsequent martyrdom) in Rome has aroused much debate in modern scholarship, not even the slightest doubt about Peter's Roman martyrdom seems to have existed in antiquity. ${ }^{7}$ The tradition was accepted very early and apparently accepted without discussion. No city other than Rome could claim the blood of Peter (and Paul), as Damasus would famously do in his epigram discussed below. The extraordinary prestige of Rome explains why the story of Peter's Roman martyrdom is first found in Eastern texts or why Western liturgical sources outside Rome do not put less emphasis on Peter's Romanness (see Rose's contribution to this volume). It was the uncontested nature of this important tradition of Peter that created an anchor stable enough to become the stronghold of a great variety of other traditions, political claims, architectural accomplishments, visual representations, liturgical developments and literary responses. This was not surprising, since references to great men from the past were abundant both in the Greco-Roman and Jewish tradition. Peter himself was anchored in Moses, the leader of the Jewish people, in early Christian art (see e.g. Dresken-Weiland's contribution). Moreover, Peter also was first, in several respects: the first man among his fellow disciples of Christ, the first bishop of Rome and the first known martyr in the city. This primacy made him an even more attractive anchor. The following paper by Hekster will further explain some of the anchoring mechanisms at work in late antiquity.

Despite the extraordinary role of the apostle Peter in political, cultural and religious history, modern publications only occasionally approach the figure of the apostle from an interdisciplinary perspective. ${ }^{8}$ This book aims to

masterclass at the Anchoring Innovation website: www.ru.nl/oikos/anchoring-innovation/. See also Hekster (2017) and, for the concept of Anchoring, Sluiter (2017) and Raimondi Cominesi (2019) 24-40.

6 Hekster (2004).

7 See for the modern debate e.g. Zwierlein $\left(2010^{2}\right)$ and responses to it, such as Heid (2011).

8 Recent exceptions are the entry for 'Petrus' in the RAC (cf. also the entry 'Paulus') and the diverse contributions in Bond and Hurtado (2015). Useful are also the proceedings of the 29th 'Incontro di studiosi dell'antichità cristiana': s.n. (2001). Popular publications are more 
contribute to a better understanding of the role of the figure of Peter with special focus on innovations that found their legitimisation in the apostle.

\subsection{Political Dimensions}

The political dimensions of Peter, both within the church and in power structures outside the religious realm, has (deservedly) attracted much attention in modern scholarship. ${ }^{9}$ Roman emperors had long tried to acquire and sustain their power with recourse to religious figures, both divine and human. The continuation of this practice into Christian times - and related to the cult of Peter - is exemplified by the edict known as Cunctos populos from 380 , in which the emperors Gratian, Valentinian and Theodosius declare that all the people submitted to them should adhere to the religion that 'the divine apostle Peter has proclaimed and transmitted to the Romans'.10 Central to Roman politics was 'the importance of religious embeddedness in conceiving and constructing positions of power, and the importance of relevant anchors in a society dominated by tradition', as Olivier Hekster states in his contribution. ${ }^{11}$ It is important to keep this in mind and to realise that not only power was anchored in the apostle Peter but the method of anchoring itself was a well-known practice of which the roots lay in a distant past.

Peter was a stable anchor, but could certainly be lifted, if necessary: as new traditions around Peter developed, they became part of the generally accepted image of the apostle and could themselves be used as anchors to introduce new traditions and practices, both as part of cult practices or in other domains of society. The case of the title pontifex maximus and its appropriation by the emperor Augustus and later, in a different form, by the Roman bishops (before early modern popes started to make use of the original pontifex maximus title again) shows the continuation of Anchoring processes from pre-Christian to Christian times. It serves as Hekster's first case-study. ${ }^{12}$ His second casestudy of anchoring processes is the city of Constantinople. Here, the emperor

numerous in this respect, e.g. in Dutch: Dijkstra and Van Espelo (2019) and Meijer (2016). Old Saint Peter's has recently been extensively discussed in McKitterick, Osborne, Richardson and Story (2014).

$9 \quad$ See e.g. Zimmermann and Michalsky (2017), Moorhead (2015) and Demakopoulos (2013).

$10 \quad$ C.Th. 16.1.2: Cunctos populos, quos clementiae nostrae regit temperamentum, in tali uolumus religione uersari, quam diuinum Petrum apostolum tradidisse Romanis religio usque ad nunc ab ipso insinuata declarat quamque pontificem Damasum sequi claret et Petrum Alexandriae episcopum uirum apostolicae sanctitatis. See Delmaire, Mommsen and Rougé (2005) 114-5.

11 Pages $28-29$

12 See also the contribution by Curran, discussed below. 
Constantine is the central figure. ${ }^{13}$ The first Christian emperor soon acquired a status among Christians that no other Roman emperor was to exceed. ${ }^{14}$ However, Constantine was soon also closely linked to the figure of Peter. Together with Paul, the rock of the church would have appeared to the emperor in a dream and (indirectly) effected his cure and conversion. ${ }^{15}$ This apostolic link was promoted most evocatively at the end of his reign, when Constantine was presented as a 13th apostle. He received his burial among the cenotaphs of the other apostles in the Church of the Holy Apostles in Constantinople. ${ }^{16}$ This event also points to the fact that anchoring in the figure of Peter also meant anchoring in the apostolic office. Hekster's two imperial case-studies thus may be read not only as an introduction to the section Peter and Power, but also as a methodological introduction to the volume as a whole, since he connects the concept of Anchoring Innovation and its use in the study of politics to Roman imperial power. As such, he outlines the context in which the figure of Peter could become an anchor in the first place.

\section{Anchoring Authority: from the East to Rome}

The city of Rome is the geographical environment that is most inextricably linked to the apostle Peter. ${ }^{17}$ This particular feature of the reception of Peter also explains the close links between him and the representatives of secular and ecclesiastical power. The focus of this volume reflects the predilection for the most ardent apostle of the gospels and the size and number of textual and material testimonies that remain from the western part of the (former) Roman Empire. Whereas there is a clear link between Paul and Rome in the New Testament, in the case of Peter this link is entirely absent. Paul's connection to Rome may have contributed to the emergence of a supposed connection of Peter to that city. The tendency of seeing the two apostles as a pair ("concordia apostolorum") certainly contributed to the universal acceptance of Rome's claim to Peter. ${ }^{18}$ Another factor was, of course, the prestige of the city of Rome

13 Cf. the contributions by Curran and Friedrichs in this volume. For links between Constantine and Augustus see e.g. Burgersdijk (2016).

14 See e.g. Linder (1975), Wortley (2004) and, most recently, Leithart in Siecienski (2017). Further references in Hekster's contribution.

15 Liverani (2008).

16 Eus. V.C. 4.6o.

17 See e.g. the contributions by Dresken-Weiland, Friedrichs, Humphries, Rose, and Thacker.

18 Cf. Huskinson (1982), Pietri (1961), and Van den Hoek's contribution to this volume. For a critique of the use of the label Concordia apostolorum for images of Peter and Paul together, see the paper by Dresken-Weiland. 
itself. As the political and cultural capital city of the empire it "deserved" the presence of the greatest disciple among the twelve as much as Peter "deserved" a place in Rome. At the same time, no other city was able to connect itself to the apostle, or if it did so (Antioch, see below), it was without denying the extraordinarily well-anchored event of Peter's death in Rome.

The veneration of Peter's grave or place of martyrdom is retraceable in the archaeological record before the publication of any (known) text that unequivocally deals with his Roman martyrdom. It was the humble start of a cult for the apostle which would soon eclipse most other Christian cults. The location at the Vatican, however, famously mentioned in Eusebius' Church History (3.25) in his reference to the trophies of the apostles Peter and Paul, offered a small meeting place for about forty people only. We have no clue as to the precise social and psychological factors that were at stake when the aedicula for Peter was built, which is still situated under the main altar of the basilica for the apostle. Equally intangible remain the function and precise history of the spot ad catacumbas along the Via Appia, where Peter and Paul were venerated together. ${ }^{19}$

This link has probably never been expressed more concisely and explicitly than by Damasus (bishop of Rome, $366-384$ ) in his famous poem on Peter and Paul that was established in the current San Sebastiano church, at the same location: 20 'The East sent its apostles, a fact we freely acknowledge. (...) Rome has earned the right to claim them as their own citizens. ${ }^{21}$ Damasus made explicit what was commonly accepted for a long time already, even in his days: Peter belonged to Rome. Consequently, since Peter belonged to Rome, Roman people in particular could use him as an anchor for numerous purposes. Still, Peter's origins in the Greek world could not and were not denied.

The largest part of Peter's life, the part also that is described in the canonical writings of the Bible that were for the most part accepted as such in an early stage, took place in Galilee. This fact resulted in an impressive reception of the figure of Peter in the region. Régis Burnet explores the image of Peter among different Christian groups as it is preserved in several texts that would soon be set aside as apocryphal by influential church leaders. They offer a glimpse

\footnotetext{
19 See especially the contribution by Van den Hoek, also those by Friedrichs and Thacker.

20 Leo I's discussion of Peter (and Paul) is another famous example of papal reference to the main apostles: see the contributions by Humphries and Thacker.

21 Ep. 20,3 and 6. For text, commentary and translation see Trout (2015) 121-2 or Aste (2014) 83-4. See also Friedrichs' contribution to this volume. For the biography of Damasus, see also Reutter (2009). On his epigrams cf. Grig (2017), Dijkstra (2016), 124-9 on epigram 20, and Sághy (2008), among many others.
} 
of the varied and original early reception of the apostle, before Peter's life became "canonised".

The early and universal acceptance of Peter as a Roman martyr appears clearly from the fact that the Greek Acts of Peter, the most ancient source providing the main details of the story of his martyrdom including his crucifixion upside down, were probably written in the East (maybe in Syria), at the end of the second century. ${ }^{22}$ The text as we have it now probably is a written composition of many other, longer stories about the apostle that once circulated. Many other apocryphal texts mention Peter, but it is the attractive narrative character and its setting in Rome which gave the Acts of Peter the success and widespread popularity for which they are known. Naturally, the focus should not be too much on this specific text, since most stories about Peter were spread orally, but the text certainly contributed to the link between Rome and the apostle. Markus Bockmuehl offers an analysis of this important text, as well as of another influential apocryphal text on Peter: the Gospel of Peter (second half of the second century). He approaches the texts with a keen eye on the portrayal of Peter's relation to Jewish and Roman power. The Passion of Christ is central to his reading of the Gospel of Peter, as well as the complex relationship between the author and the apostle in whose name he wrote. In the Acts of Peter it is his combat with Simon the Magician (see below) and the account of Peter's martyrdom as an act of resistance to Roman power that are brought to the fore.

\subsection{Casting an Anchor in Stone}

With the quotation from Damasus' epigram a specific category of texts was mentioned, which had a large impact on society in late antiquity in particular: epigraphical writings. The so-called Roman 'epigraphic habit' waned after the early imperial period, but made a comeback in the late third and fourth centuries, when Christians increasingly discovered the potential of inscribed texts for the promotion of their faith (and themselves). ${ }^{23}$ Damasus was not unique in his epigraphical endeavours. Christian buildings where adorned with inscriptions from the very start, as is clear from the famous inscription by Constantine in old Saint Peter's. ${ }^{24}$ The emperor of course continued a longstanding practice of Roman emperors erecting inscriptions on and in public

22 For a recent analysis of the apocryphal traditions around Peter see Burnet (2014), 220-39 in particular. See also the author's contribution to this volume and that of Bockmuehl and Thacker discussed below.

23 See e.g. Trout (2012), who has published extensively on late Roman epigraphy, and Carletti (2008), also Bolle, Machado, and Witschel (2017).

24 ICUR 2.4092, see e.g. Liverani (2007a; 2014). 
buildings. Soon, Christian bishops acknowledged the possibilities of inscriptions too. Whereas the epigrams by Damasus have received a lot of attention, many other inscriptions still remain somewhat in the shadow of literary texts, despite their historical and literary significance. For Thomas Noble, by contrast, the innovative use of epigraphy by Damasus is only the start of an investigation of the epigraphical habit of the Roman episcopate up to Sergius I (687-701), which includes thirty-two churches with non-fragmentary, securely datable papal inscriptions. Naturally, some well-known churches devoted to Peter, notably old St Peter's and San Pietro in Vincoli, are among them. A full discussion of inscriptions cannot but include various other aspects of episcopal responsibilities, such as liturgical duties, architectural endeavours and visual representation (also discussed elsewhere in this volume, cf. the contributions by Friedrichs, Löx, Rose, and Thacker in particular). The use of inscriptions was yet another means by which the popes put their mark on buildings and locations across the city of Rome. References to Peter were part of this effective practice.

The mentioning of offices is an important feature of inscriptions in antiquity. As mentioned earlier, Hekster discusses this case briefly and enlightens its imperial context. John Curran traces the origins of the episcopal office in order to fully understand the meaning of the peculiar papal appropriation of the title of pontifex maximus. It is the process of this appropriation rather than the finalizing act itself that deserves our interest. Moreover, Curran rightly points to the ambiguous benefits of Constantine's interventions in the Church. The case of the title pontifex maximus shows the various ways in which the concept of Anchoring can be applied. Whereas Hekster sees the use of the title by the popes primarily anchored in its imperial and traditional connotations, Curran emphasises the importance of a passage in the historiographical work of Zosimus in which the papal use of the title is anchored.

\section{Verbal and Visual Images of the Apostle and the Quest for a Petrine Map of Rome}

Given the intimate link between the apostle Peter's mostly praised biographical events and the city of Rome, it might not come as a surprise that it was in the capital of the Roman Empire that a set of petrine images was developed, from the middle of the third century onwards. ${ }^{25}$ Most of the images have a

25 Nevertheless, the first known public image of Peter in a narrative context was made in Dura Europos (Syria). Peter was depicted in a Christian house church dated to the middle 
strong symbolic meaning related to the funerary context in which the vast majority of them is found. This symbolic meaning can often easily be connected to well-known texts: the arrest of Peter (as the non-violent depiction of his martyrdom described in the Acts of Peter) or (the prediction of) his denial of Christ and subsequent rehabilitation (Matt. 26.31-35; 69-75, and parallel passages; John 21).

Jutta Dresken-Weiland reveals how these images of Peter were anchored in the visual traditions of Rome. The city appears to be extremely important and closely connected to petrine iconography. The primacy of Peter itself and the apostle's possession of the keys of heaven were not a popular subject among the craftsmen and commissioners of early Christian art, but Peter's outstanding position was reflected by a large and hardly paralleled variety of images that referred to different stages of his life. One of the most popular and most intriguing of those images was of course the visualisation of his death in Rome. Markus Löx focuses on this particular image and on its much discussed nonviolent nature in particular. Martyrdom was one of the more curious and heavily criticised aspects of early Christianity, which even aroused discussions in its own circles. Images of martyrdom certainly had to be anchored in Rome's visual tradition in order to support their acceptance. The column of Marcus Aurelius is one example of a monumental structure showing images of violence. At the same time, the depiction of Peter's crucifixion was necessarily related to other depictions of Christian martyrdom and to that of Christ in particular, as Löx shows.

Among other scenes, Dresken-Weiland (see also the contributions by Thacker and Löx) discusses Peter's water miracle and the apostle's fight with Simon the Magician. Both are closely related to specific spots in the Roman landscape (see Thacker's contribution in particular) and to the Forum Romanum specifically. As such, they are exemplary for a broader development in late antique and early mediaeval cult of Peter, in which the topography of the city gradually became more closely linked to the memory of Peter. Moreover, these images reveal that the variety of stories in which the apostle played an important role was probably greater than is suggested by the repertoire now known to us. The water miracle scene can function as a case in point: it is an often repeated image, originating in the fourth century, that is part of the so-called petrine cycle, together with the two other widely distributed

of the third century, see Korol (2011) 1622-43. The oldest image of Peter that is known is a charcoal graffito of his head (now barely visible) found during the excavations at the Vatican necropolis, see Liverani and Spinola (2010) 328. 
scenes mentioned above. ${ }^{26}$ The scene shows an apostle who is recognisable as Peter in most cases, because of his curly hair and round beard. With a staff, this figure touches a vertical stream of water falling from a rock. Some men (mostly two) kneel and drink from the water. There are characterised by their pileus pannonicus, a headgear that signals them as soldiers. ${ }^{27}$ The staff or virga in the hands of Peter is a clear sign of the miraculous nature that is inherent to the scene. ${ }^{28} \mathrm{An}$ intriguing aspect of this image is the fact that visual sources antedate textual testimonies to this miracle. The Martyrium beati Petri apostoli a Lino conscriptum (fifth century) and the Passio sanctorum martyrum Processi et Martiniani (sixth century) both post-date the fourth-century images of the water miracle. They tell a story that is clearly related to the well-known image, although they may reflect a different tradition. ${ }^{29}$ Interestingly, the first written source is pretended to be written by Linus, the traditional successor of Peter as bishop of Rome. ${ }^{30}$ The second source is most elaborate on the story. It appears that a topographical spot is added to it, which suggests a connection to the Mamertine prison, close to the Forum Romanum:

Tempore quo Simon magus crepuit intus et impiissimus Nero tradidit beatissimos apostolos Christi Petrum et Paulum Paulino uiro clarissimo magisteriae potestatis, eodem tempore Paulinus mancipavit beatissimos apostolos in custodia Mamertini. (...)

Erant autem custodientes eosdem beatissimos apostolos milites multi, inter quo erant duo magistriani melloprincipes, Processus et Martinianus. (...) At vero beatissimi apostoli oraverunt in eadem custodia: cumque orassent, illico beatus Petrus apostolus facto signo crucis in monte Tarpeio, in custodia Mamertini, eadem hora emanaverunt aquae de monte. Tunc baptizati sunt beati Processus et Martinianus magistriani melloprincipes a beato Petro apostolo. Hoc dum vidissent cuncti qui in custodia erant, prostraverunt se ad pedes beati Petri apostoli et baptizati sunt promiscui sexus et aetatis numero quadraginta septem. ${ }^{31}$

26 See e.g. Dijkstra (2016) 346-62, 346-51 in particular, and the contribution by DreskenWeiland with figure 1.

$27 \quad$ Ubl (1976).

28 Recently on the virga as a non-magic motif from classical iconography see Jastrzębowska (2015). To my view, the more down-to-earth provenance of the virga does not alter its significance as a magical instrument in early Christian iconography.

29 I will go into more detail in a forthcoming publication provisionally entitled L'apôtre Pierre et ses miracles de la source.

$30 \quad$ For more information on the text see e.g. Schneemelcher $\left(1999^{6}\right) 392$.

31 Passio sanctorum martyrum Processi et Martiniani 1, 3 and 9. Text and discussion in Franchi De' Cavalieri (1953). 
It was in the days when Simon the magician burst open from inside and the heathenish Nero delivered Peter and Paul, the most blessed apostles of Christ, to Paulinus, an excellent man with magisterial power. At that time, Paulinus handed the most blessed apostles over to the custodia Mamertini. (...) Many soldiers were guarding those most blessed apostles, two magistriani melloprincipes, Processus and Martinianus, being among them. (...) And the most blessed apostles have prayed in that prison. And when they had prayed, the apostle Peter made there the sign of the cross in the Tarpeian rock, inside the custodia Mamertini, and at the same time streams of water sprung from the rock. Then the blessed magistriani melloprincipes Processus and Martinianus were baptised by the blessed apostle Peter. When the other prisoners had seen this, they prostrated at the blessed apostle Peter's feet and they were baptised, different in sex and age; 47 in number.

There are some notable differences between the story and the images that I just described. Most revealing regarding the development of the petrine cult, however, might be the mentioning of specific local Roman spots where this all happened, even if it is impossible to reconcile Roman topography and the designations used in the story entirely. ${ }^{32}$ I have signalled out this scene because it might help us to consider the many ways in which stories with Peter as the main protagonist could arise. We do not have any certainty about the original order of the development of the story. On the basis of the material now known to us, images of a new petrine miracle (clearly anchored in a similar miracle performed by Moses in the desert and mainly shown in the catacombs) arose in the beginning of the fourth century and were connected to a story about the saints Processus and Martinianus, for whom a church was erected that existed already in the fourth century. ${ }^{33}$ This led to a rather extensive story about the two saints, in which Peter played an important role. As was common, Paul was also connected to the story, since he and Peter were supposed to have suffered martyrdom in the same period (if not on exactly the same day). As the tradition grew, the need for a demonstrable place within the city of Rome was felt and the story was connected to the famous prison of ancient Rome: the Mamertine prison. But the order of this development might have been different as well. It is the reciprocal influence of texts, visual traditions and topographical aspects that is most interesting.

32 See, among others, LTUR s.v. Custodia Mamertini.

33 Verrando (1981), 275 in particular. 
Peter thus came to be connected to the heart of the ancient city. His widely popular struggle with Simon the magician (mentioned in the passio of Processus and Martinianus cited above; cf. also Dresken-Weiland's and Thacker's contribution) was thought later on to have taken place at the Forum too. In this way, the centre of the classical city was claimed for the Christian case, not only by the construction of churches but also by the composition of stories. Peter himself became anchored in the heart of the city. Although his resting place could be found at the Vatican, at the other side of the Tiber, he now entered the topographical key sites of Rome's glorious history. It was here that monuments for the heroes of the pre-Christian past could be found that had been famous for a long time, such as the Niger lapis or the statue of Romulus, Remus and the she-wolf. ${ }^{34}$

In this volume, Mark Humphries also mentions the hut of Romulus on the Palatine hill, in his inquiry into the clash between two visions of history: that of the traditional story of the actual foundation of the city by Romulus (and Remus) and the newly propagated metaphorical foundation of Christian Rome by Peter (and Paul). Whereas Christians sometimes struggled to define the right relation between the two apostles and their reciprocal authority (cf. Van den Hoek's contribution), the case of Rome's traditional founders was much more complicated: the one had killed the other. He even did so in the heart of the Roman city, on the Forum, as Orosius remarks. ${ }^{35}$ Humphries signals the progressing influence of the story of the Christian foundation of Rome and the receding attraction of traditional foundation myths (at least among Christians) in the fourth and fifth centuries. At the same time, adaptations to the Roman landscape of commemoration reflected this shift of ideas.

Humphries' contribution testifies to the growing importance of poetry in late antiquity. ${ }^{36}$ Already the first openly Christian poet Juvencus ( $f l$. 330), starting the long tradition of Christian verse, paid more attention to Peter in his biblical epic than his biblical source text and poetical strategy required..$^{37}$ One of his later successors, in the fifth century, was the poet Sedulius. Carl Springer

34 For an excellent discussion of the way in which one could make use of these memorials to strengthen one's power, see Hunsucker (2018) on Maximian and Maxentius, also discussing the Niger lapis and statue. For possible locations of commemorative monuments on the Forum see Carandini, Carafa and Halavais (2017) Tab. 21. For the fight over Rome's topography between traditionalists and Christians, see e.g. Schmitzer (2012).

Orosius 2.4.4: Primus illi (sc. Romulus) campus ad bellum forum urbis fuit, mixta simul externa ciuiliaque bella numquam defutura significans. Text quoted by Humphries in this volume.

36 Cameron (2004).

37 See Dijkstra (2016), 89-95 in particular. Also Müller (2016) 39-61. 
shows that the context in which his Paschale carmen was written was of eminent importance to a better understanding of the representation of Peter in the poem. Peter's role in the denial of Christ and its aftermath in John 21 (of which the visual expression is discussed extensively in the contribution by Dresken-Weiland) is taken as a case-study to show the poetic latitude which the poet granted himself in his versification of the canonical gospels. Sedulius' view on Peter cannot be separated from that of other poets (e.g. Prudentius: see above and the contribution by Humphries) and exegetes: it was anchored in widespread ideas about the figure of Peter in Christian culture.

Apart from poetry and iconography, the veneration of Peter in Rome also influenced its architectural outlook. The most conspicuous location for the cult of Peter was of course the Vatican, connected to his death. Kristina Friedrichs proposes a three-stage model of architectural appropriation and zooms in on the similarities and differences with the anchoring innovation concept in her analysis of architectural structures commemorating Peter at the Vatican and ad catacumbas. ${ }^{38}$ Both places were created 'from below' and not controlled by any Christian authorities. From Constantine onwards, Peter became an anchor for different members of the Christian community. Naturally, he was not the only anchor. At the end of the fourth century, the apostle Paul became remarkably popular in Rome (cf. the contribution by Van den Hoek); the renewal of the San Paolo fuori le Mura church was only one eye-catching result of this popularity. ${ }^{39}$ But Peter regained lost ground in the fifth century and St. Peter's became more and more important. During the strife for power between Symmachus and Laurentius, the prestigious image of the church for Peter was effectively used, testifying to the firm anchor that Peter had become. ${ }^{40}$

As we have seen, the absence of geographically traceable petrine spots in the West that were legitimised by the narrative of the New Testament meant that people went out looking for (in particular) Roman places where God's work in the life of the apostle was still tangible. These places could be directly linked to the cult for the apostle, such as the Vatican and the location ad catacumbas along the Via Appia, and/or to events in the life of the apostle. In the fourth century, this practice flourished and led to more and more Petrine spots in Rome. ${ }^{41}$ The apostle functioned as an anchor for new ritual and liturgical

\footnotetext{
38 The location ad catacumbas is also central to the contribution by Van den Hoek.

39 Eastman (2011), Dassmann (2015a).

$40 \quad$ See e.g. Wirbelauer (1994) 415-6.

41 See for a topographical approach towards Peter's presence in the city e.g. Susman (1964) and Spera (1998), also Cecchelli (200o). Denzey Lewis (2018) points to the dangers implied by the modern phraseology about a "petrine map of Rome" when seen as a preconceived papal construct.
} 
practices that stimulated also new stories that contributed to the existence of a full biography for the figure of the saint (see below).

The Christianisation of the Forum, in which the apostle Peter played a role, as signalled above, made it into a place that attracted ecclesiastical events of political nature. ${ }^{42}$ An example can be found in the eight century, when political turmoil broke out after the death of pope Paul I (757-767). While the pious Stephanus kept watch at the bed of the dead pope, a certain Constantine (!) occupied the papal see and was consecrated in St Peter's. After this inaudita novitas better known as Constantine II had been soon dismissed by the primicerius Christopher and his son Sergius, with the help of the Lombards, a certain Waldipert proclaimed the presbyter Philip pope. Or rather, the apostle Peter did, as the acclamation of Philip suggests: Philippum papam sanctus Petrus elegit. However, the new pope was soon brought back to his monastery (which was a blessing after all, when we compare his fate to that of other papal pretenders) by the aforementioned Christopher and Sergius. Then, finally, Stephanus, the third with this name, became bishop of Rome (768-772; Liber Pontificalis 96.11):

Sicque praefatus Christoforus primicerius alio die aggregans in Tribus fatis omnes sacerdotes ac primatus cleri et optimates militiae atque universum exercitum et cives honestos, omnisque populi Romani coetum, a magno usque ad parvum, pertractantes, pariter concordaverunt omnes una mente unoque consensu in persona praefati beatissimi Stephani; pergentesque in titulo beate Cecilie, in quo presbiter existens spiritalem degebat vitam, eum pontificem elegerunt.

Thus, on the next day, the aforementioned primicerius Christopher gathered all priests and first-rate clergy and noble men as well as the entire army and honourable citizens and an assembly of all the Roman people, old and young, for consultation at the Three Fates. Together they have all agreed unanimously, of one accord, for the person of the aforementioned most blessed Stephen. And proceeding to the church of blessed Cecilia, where he spent his time serving as a priest, they chose him as their pontiff.

See e.g. Kalas (1999); also Diefenbach (2007) and Muth (2012). The Acts of Sylvester were another important factor, see e.g. Pohlkamp (2007) 111: ‘(...) besiegelt der Anonymus der römischen Silvester-Akten mit seiner mythographischen Schlusserzählung die Neugründung der Roma Christiana zur Zeit Silvesters und Konstantins auf dem Forum Romanum als dem alten pagan-religiösen Zentrum der Stadt und des Erdkreises.' 
Christopher, the man in charge at the time, chose to gather the people at the heart of the ancient city, on the Forum, next to the Curia (which had already been turned into the Sant'Adriano church in the year 630). Nearby, Paul I had built a church to commemorate the prayer of Peter and Paul to God resulting in their demonic competitor Simon the Magician to crash after his (initially successful!) attempt to fly. The prints of their knees were still visible in stone, according to the Liber Pontificalis. ${ }^{43}$

From the conquest of Rome's old political centre it was only a small step to a remarkable political event, that took place in Peter's main church: the coronation of Charlemagne in St. Peter's. From a reconstruction of the events preceding Charlemagne's coronation appears clearly that it was a well-considered act that brought advantages to both pope and emperor, although the latter controlled the situation. ${ }^{44}$ The event testifies to the popularity of the apostle also outside the city of Rome. ${ }^{45}$ The emperor was acclaimed in front of the confessio of the apostle. ${ }^{46}$

\section{4}

\section{Creating the Apostle's Cult}

Throughout the discussion of anchoring practices in the apostle, a legendary biography of Peter has gradually emerged. The need for an "official", written version of such a biography is understandable also given the growing importance of the cult and cult places for the apostle. We already saw the example of the Acta Petri mentioned above. However, Roman versions also emerged, such as those of Jerome and the compilers of the Liber pontificalis.

\subsection{A Biography for the Apostle}

All these places and memorials related to the apostle had to be connected to a (at least to some extent coherent) biography of Peter. At the same time, this biography was probably also built under influence of petrine locations, since no canonical text provided the essential information about Peter's life after his escape from prison in Jerusalem (Acts 12.3-19). Efforts were made to bring the

$43 \quad L P$ 95.6. A relic of this kind is still stored in the Santa Francesca Romana church near the Forum. The fight of Peter (and Paul) with Simon the Magician is one of the subjects of Eastman (2019) which, unfortunately, appeared too late to take into account in this volume, but testifies to the ongoing interest in the figure of Peter, his death, and his relationship to Paul.

44 See e.g. Collins (1998).

45 See e.g. De Blaauw (2018), 141 in particular, Favier (1999) 544.

$46 \quad L P$ 98.23-4. 
essentials together in texts such as Jerome's De viris illustribus and of course in the Liber Pontificalis that was already cited above. Both texts start off with a (very short) biography of the apostle Peter. Although written in different times (end of the 4th versus first half of the 6th century respectively) and with different purposes, a brief comparison of the two texts may give an impression of the shifting attitudes towards and diverging interests in the apostolic figure of Peter. The texts are linked through the status of Jerome among Christians of the sixth century ${ }^{47}$ This status is apparent from a letter to Damasus fictitiously signed by the Church father, that precedes the biographies in the Liber pontificalis. The papal claim to primacy is made clear from the very beginning by Jerome, who asks Damasus to 'please sum up in orderly fashion all the events around your see from the principate of the blessed apostle Peter to your days.' ${ }^{48}$

Both the De viris illustribus and the Liber Pontificalis start providing some biographical information about Peter's background. Essentially, this is the period in Peter's life before he entered Rome (birthplace, family, stay in Antiochia). In Jerome's work, Peter's coming to Rome is explicitly described: ad expugnandum Simonem magum, Romam pergit (he came to Rome in order to chase Simon the Magician). The Liber Pontificalis keeps it short and plain: hic Petrus ingressus in urbe Roma. This is different from the reference to Peter's arrival in Antiochia, which is absent as an event in its own right. Only the bare fact of his episcopate in that city is mentioned in both sources. Jerome immediately puts much weight on the way in which Peter died, upside down because of his humble character. ${ }^{49}$ What follows is information about Peter's oeuvre, in which the greater emphasis on apocrypha by Jerome reflects the more pertinent discussion of canonicity in his days (and the ambiguous status of 2 Peter). As a document written by the papal chancellery, the anachronistic emphasis on the number of Peter's appointments to ecclesiastical offices in the Liber Pontificalis does not come as a surprise. Both sources close with the location of Peter's grave and mention the Vatican and the Trionfale area. ${ }^{50}$ However, the Liber Pontificalis feels the need to emphasise the ancient roots of this area and mentions (once again) the link to Nero (i.c. his palace) and a temple of Apollo.

\footnotetext{
47 See for the context in which the $L P$ was written and also the role of the figure of Jerome e.g. McKitterick (2009).

48 (...) ut actus gestorum a beati Petri apostoli principatum usque ad vestra tempora, quae gesta sunt in sedem tuam, nobis per ordinem enarrare digneris: LP, Duchesne (1886) 49 (restitution).

49 A quo et adfixus cruci martyrio coronatus est capite ad terram verso et in sublime pedibus elevatis: asserens se indignum qui sic crucifigeretur, ut Dominus suus. Text: Bernoulli (1968 [1895]).

See Triumphalis territurium, LTUR 5: 201-202 (Liverani).
} 
Probably, this extra information indicates a desire to have the apostle surpass the symbols of Rome's pagan past as well as a lack of knowledge about ancient Roman topography in contrast with the living memory to what was there before old St Peter's was built at the time of Jerome. The temple of Apollo is most probably to be understood as a Phrygianum. ${ }^{51}$ In this final sentence, Peter's death by crucifixion is mentioned for the first time in the pontifical biography.

The great number of legends about the apostle, growing over time, notwithstanding, even in the sixth century it was the mere fact of Peter's death in Rome that was essential to the claims that were made to the apostle. The location of his grave still mattered, as did his relation to the prestigious past of ancient Rome, of which the remains impressed visitors and inhabitants alike even in the sixth century. ${ }^{52}$

\subsection{Anchoring the Cult of Peter}

One difference between the two sources has not yet been mentioned: although Jerome provides most information on Peter's death, it is the Liber pontificalis that mentions the fact that he died together with Paul. ${ }^{53}$ In her contribution Annewies van den Hoek delves into the intricacies of the reception of the close relationship between Rome's most important saintly figures. She shows how initial confusion in the (Greek) sources about Paul's possible Roman episcopate ultimately resulted in a widespread preference for the apostle Peter, although Paul's Roman connection is stronger in the most ancient sources. ${ }^{54}$ Literary (canonical, apocryphal and patristic), epigraphical and visual testimonies are all included in her attempt to unravel the development of Peter's popularity over Paul. The different views on the apostle, which were already apparent from the alternative presentations of Peter investigated by Bockmuehl and Burnet, also come to the fore and remind us once again that the anchor that Peter was could only be used effectively when local culture and convictions were taken into account. Van den Hoek shows that Peter and Paul were considered as a pair from the very beginning of Christian cult, but also how many attempts were made to give the one preference over the other.

This is only one aspect of a cult for the apostle that pervaded all aspects of Roman society. Especially from the fourth century onwards, the figure of Peter became virtually omnipresent in the cultural landscape of Christians, in Rome in particular. Alan Thacker shows this development with a bird eyes

\footnotetext{
$51 \quad$ Liverani (1999) 31.

52 Cf. Diefenbach (2007).

53 Hic matryrio cum Paulo coronatur.

54 Cf. also Gahbauer (2001).
} 
view perspective, discussing all important ways in which people came to know the apostle. Starting with some of the apocryphal texts - with a keen eye for the connection of Peter with Paul and the city of Rome - Thacker points to the iconographical, poetic and geographical developments in the petrine cult, focusing on the fourth and fifth century in particular. Thacker shows the general trends appearing from the development in a wide array of different media and practices.

Peter's presence in the cultural and social life of early Christian and mediaeval society was not restricted to locations, biographies, images and Christian poetry in classical style. Naturally, Peter was invoked in many liturgical texts, and certainly not only in Rome, as Els Rose shows in her contribution. The importance of Peter's liturgical role is evident: after all, it was on liturgical feast days devoted to Peter, such as those commemorating the traditions around his chair (22 February), his martyrdom (29 June) and his chains (1 August), that people were remembered of the role of the apostle in a most explicit (and festive) way. Peter's denial again plays an important role, since the tears of repentance could symbolise a second baptism. The liturgical record inside and outside Rome (Gaul, Spain) turns out to show an un equivocal, though not universal, preference for certain (Roman) events from Peter's life that are particularly popular in other fields too, such as his denial (in poetry and iconography; see Springer and Dresken-Weiland in particular), his combat with Simon Magus (see above; also Dresken-Weiland) and his death (Löx). As Rose puts it: 'The choice of sources that underlie the liturgical portrait of Peter shows that every effort was made to add to the innovative quality of Peter's cult, even more so outside Rome than in Rome itself'. 55

\section{5}

\section{The Fisherman as Anchor}

Many more examples of the importance of traditions around the figure of the apostle are discussed in this book, making it a truly interdisciplinary collection of papers. Each paper is related to several others, which makes an undisputed ordering almost impossible. The contributions are divided into three sections in the knowledge that other divisions could have worked too. Cross-references between contributions as well as between sections are added in order to present the many intersections more clearly to the reader. 
Together the contributions offer a kaleidoscopic impression of the way in which Peter became an anchor for many communities, individuals, and institutions. They could anchor in the memory of the apostle: in a first period this was living memory, but soon it became the memory of a foregone period, that was transmitted orally, in written form and by other means. It was also possible to anchor in the first testimonies of that memory: the documents (supposedly) written by the apostle, buildings dedicated to him, memorials of events in which he played a role, rituals related to the apostle and literary, epigraphical and visual traditions that had been developed around him. The multi-layered "harbour" that has thus come into existence still plays an important role in the anchoring processes that are ongoing within and outside the Church of the present day. This collection of essays describes how the humble fisherman from Galilee has become an anchor for the entire Mediterranean region and beyond, till the present day.

\section{Bibliography}

Aste, A. 2014. Gli Epigrammi di Papa Damaso I. Tricase: Libellula Edizioni.

Bernoulli, C. A. 1968 (1895). De viris inlustribus. Hieronymus und Gennadius. Frankfurt: Minerva.

Bolle, K., C. Machado \& C. Witschel. 2017. The Epigraphic Cultures of Late Antiquity. Stuttgart: Franz Steiner Verlag.

Bond, H. K. \& L. W. Hurtado. 2015. Peter in Early Christianity. Michigan:Wm. B. Eerdmans.

Burgersdijk, D. 2016. De macht van de traditie. Het keizerschap van Augustus en Constantijn. Amsterdam: Athenaeum - Polak \& Van Gennep.

Burnet, R. 2014. Les douze apôtres. Histoire de la réception des figures apostoliques dans le christianisme ancien. Turnhout: Brepols.

Cameron, A. 2004. Poetry and Literary Culture in Late Antiquity. In Approaching Late Antiquity: the Transformation from Early to Late Empire, ed. S. Swain \& M. J. Edwards, 327-54. Oxford: Oxford University Press.

Carandini, A., P. Carafa \& A. C. Halavais. 2017. The Atlas of Ancient Rome: biography and portraits of the city. Princeton, New Jersey: Princeton University Press.

Carletti, C. 2008. Epigrafia dei cristiani in occidente dal III al VII secolo. Ideologia e prassi. Bari: Edipuglia.

Cecchelli, M. 200o. I luoghi di Pietro e Paolo. In Christiana loca I, ed. L. Pani Ermini, 89-97. Roma: Fratelli Palombi Editori.

Dassmann, E. 2015a. Paulus IV (Ikonographie u. Kult). In RAC 26: 1229-1250. Stuttgart: Anton Hiersemann. 
Delmaire, R., T. Mommsen \& J. Rougé. 2005. Les lois religieuses des empereurs romains de Constantin à Théodose II. Paris: Les Éditions du Cerf.

Demakopoulos, G. E. 2013. The Invention of Peter. Apostolic Discourse and Papal Authority in Late Antiquity. Philadelphia: University of Pennsylvania Press.

Den Boeft, J. 1993. Ambrosius lyricus. In Early Christian poetry: a collection of essays, ed. J. Den Boeft \& A. Hilhorst, 77-89. Leiden/Boston: Brill.

Denzey Lewis, Nicola, 2018. Damasus and the derelict relics. Early Medieval Europe 26,4: 417-39.

Diefenbach, S. 2007. Römische Erinnerungsräume: Heiligenmemoria und kollektive Identitäten im Rom des 3. bis 5. Jahrhunderts n. Chr. Berlin: Walter de Gruyter.

Dijkstra, R. 2016. The Apostles in Early Christian Art and Poetry. Leiden/Boston: Brill.

Dijkstra, R. \& D. Van Espelo. 2017. Anchoring Pontifical Authority: A Reconsideration of the Papal Employment of the Title Pontifex Maximus. Journal of Religious History 41(3): 312-25.

Dijkstra, R. \& D. Van Espelo. 2017a. Anchoring authority in St Peter's grave - imperial and ecclesiastical politics at the confessio from Antiquity to the early Middle Ages. In Die Päpste und Rom zwischen Spätantike und Mittelalter. Formen der päpstlichen Machtentfaltung (Internationale Konferenz 17.-19. März 2016), ed. N. Zimmermann \& T. Michalsky, 237-50. Regensburg: Schnell \& Steiner.

Dijkstra, R. 2018. Imagining the Entrance to the Afterlife. Peter as the Gatekeeper of Heaven in Early Christianity. In Sacred Thresholds. The Door to the Sanctuary in Late Antiquity, ed. E. B. Van Opstall, 187-218. Leiden/Boston: Brill.

Dijkstra, R. \& D. Van Espelo. 2019. Petrus in Rome. Tastbare resten van de oudste Petrustradities. Antwerpen/Apeldoorn: Garant.

Eastman, D. L. 2011. Paul the Martyr. The Cult of the Apostle in the Latin West. Atlanta: Society of Biblical Literature.

Eastman, D. L. 2019. The Many Deaths of Peter and Paul. Oxford: Oxford University Press.

Franchi De' Cavalieri, P. 1953. Della custodia Mamertini e della Passio Ss. Processi e Martiniani. Note agiografiche 9: 3-52.

Gahbauer, F. 2001. Petrus und Paulus in Rom. Sprachlich und ekklesiologisch bedingte Tendenzen zugunsten des Petrus oder Paulus in den Texten (2.-4. Jh.)? In Pietro e Paolo. Il loro rapporto con Roma nelle testimonianze antiche. XXIX Incontro di studiosi dell'antichità cristiana, 155-167. Roma: Institutum Patristicum Augustinianum.

Grig, L. 2017. Cultural Capital and Christianization: The Metrical Inscriptions of Late Antique Rome. In The Epigraphic Cultures of Late Antiquity, ed. K. Bolle, C. Machado and C. Witschel, Stuttgart: Franz Steiner Verlag.

Heid, S. 2011. Petrus und Paulus in Rom. Eine interdisziplinäre Debatte. Freiburg am Breisgau: Herder. 
Hekster, O. 2004. The constraints of tradition. Depictions of Hercules in Augustus' reign. In Orbis antiquus. Studia in honorem Ioannis Pisonis, ed. C. Gazdac et alii, 235-41. Cluj-Napoca: Nereamia Napocae Press.

Hekster, O. 2017. Religion and tradition in the Roman Empire: Faces of Power and Anchoring Change. Journal of Ancient Civilizations 32: 13-34.

Hengel, M. $2007^{2}$. Der unterschätzte Petrus. Zwei Studien. Tübingen: Mohr Siebeck.

Hunsucker, R. 2018. Maxentius and the aeternae urbis suae conditores: Rome and its Founders from Maximian to Constantine (289-313). In Imagining Emperors in the Later Roman Empire, ed. D. W. P. Burgersdijk \& A. J. Ross, 83-112. Leiden/Boston: Brill.

Huskinson, J. M. 1982. Concordia Apostolorum. Christian Propaganda at Rome in the Fourth and Fifth Centuries. A study in Early Christian Iconography and Iconology. Oxford: BAR.

Jastrzębowska, E. 2015. Virga in the Hands of Christ, Moses and Peter: Pagan Heritage or Christian Novelty. Światowit. Annual of the Institute of Archaeology of the University of Warsaw XII (LIII; 2014-A): 99-110.

Korol, D. 2011. Neues zu den alt- und neutestamentlichen Darstellungen im Baptisterium von Dura-Europos. In Ablution, Initiation, and Baptism. Late Antiquity, Early Judaism, and Early Christianity, ed. D. Hellholm, T. Vegge, Ø. Norderval \& C. Hellholm, 1611-72. Berlin/Boston: De Gruyter.

Linder, A. 1975. The Myth of Constantine the Great in the West: Sources and Hagiographic Commemoration. Studi Medievali 16(1): 43-95.

Liverani, P. 1999. La topografia antica del vaticano. Città del Vaticano: s.n.

Liverani, P. 2007a. L'architettura costantiniana tra committenze imperiale e contributo delle élites locali. In Konstantin der Große. Geschichte - Archäologie - Rezeption (Akten des Internationales Kolloquiums, 10.-15. Oktober 2005, Trier), 235-244. Trier: Rheinisches Landesmuseum Trier.

Liverani, P. 2008. Saint Peter's Leo the Great and the leprosy of Constantine. Papers of the British School at Rome 76: 155-72.

Liverani, P. 2014. Chi parla a chi? Epigrafia monumentale e immagine pubblica in epoca tardoantica. In Using Images in Late Antiquity, eds. S. Birk, T. M. Kristensen \& B. Poulsen, 3-32. Oxford: Oxbow Books.

Liverani, P. \& G. Spinola. 2010. Die Nekropolen im Vatikan. Milano/Stuttgart:Jaca Book/ Belser.

McKitterick, R. 2009. La place du Liber pontificalis dans les genres historiographiques du haut Moyen Âge. In Liber, Gesta, histoire. Écrire l'histoire des évêques et des papes de l'Antiquité au XXIe siècle, ed. F. Bougard \& M. Sot, 23-35. Turnhout: Brepols.

McKitterick, R., J. Osborne, C. M. Richardson \& J. Story. 2014. Old Saint Peter's, Rome. Cambridge: Cambridge University Press. 
Meijer, F. 2016. Petrus: leerling, leraar, mythe. Amsterdam: Athenaeum-Polak \& Van Gennep.

Moorhead, J. 2015. The popes and the Church of Rome in late antiquity. New York: Routledge.

Müller, M. 2016. Tod und Auferstehung Jesu Christi bei Iuvencus (IV 570-812). Untersuchungen zu Dichtkunst, Theologie und Zweck der Evangeliorum Libri Quattuor. Stuttgart: Franz Steiner Verlag.

Muth, S. 2012. Der Dialog von Gegenwart und Vergangenheit am Forum Romanum in Rom. Oder: Wie spätantik ist das spätantike Forum? In Rom und Mailand in der Spätantike. Repräsentationen städtischer Räume in Literatur, Architektur und Kunst, ed. T. Fuhrer, 263-82. Berlin/Boston: De Gruyter.

Pietri, Ch. 1961. Concordia apostolorum et renovatio urbis (Culte des martyrs et propagande pontificale). Mélanges de l'école française de Rome 73: 275-322.

Pohlkamp, W. 2007. Konstantin der Große und die Stadt Rom im Spiegel der römischen Silvester-Akten (Actus Silvestri). In Kaiser Konstantin der Grosse. Historische Leistung und Rezeption in Europa, ed. K. M. Girardet, 87-112. Bonn: Verlag Dr. Rudolf Habelt.

Raimondi Cominesi, A. 2019. The Past on the Wall. Anchoring Political Innovation in the Decoration and Architecture of the Imperial Residences on the Palatine (44 BCE$235 C E)$. Nijmegen, Radboud Universiteit Nijmegen.

Reutter, U. 2009. Damasus, Bischof von Rom (366-384). Leben und Werk. Tübingen: J.C.B. Mohr (Paul Siebeck).

s.n. 2001. Pietro e Paolo. Il loro rapporto con Roma nelle testimonianze antiche. XXIX Incontro di studiosi dell'antichità cristiana. Roma: Institutum Patristicum Augustianianum.

Sághy, M. 2008. Poems as Church History: The Epigrams of Pope Damasus. In Motivi e forme della poesia cristiana antica tra scrittura e tradizione classica, ed. s.n., 487-96. Roma: Institutum Patristicum Augustinianum.

Schmitzer, U. 2012. Der symbolische Kampf um die römische Topographie im christlichpaganen Diskurs. In Rom und Mailand in der Spätantike. Repräsentationen städtischer Räume in Literatur, Architektur und Kunst, ed. T. Fuhrer, 237-61. Berlin/Boston: De Gruyter.

Schneemelcher, W. $1999^{6}$. Neutestamentliche Apokryphen. II. Apostolisches, Apokalypsen und Verwandtes. Tübingen: J.C.B. Mohr (Paul Siebeck).

Siecienski, A. E. 2017. Constantine: Religious Faith and Imperial Policy. London/New York: Routledge.

Sluiter, I. 2017. Anchoring Innovation: a classical research agenda. European Review 25(1): 20-38.

Spera, L. 1998. Ad limina apostolorum. Santuari e pellegrini a Roma tra la tarda antichità e l'alto medioevo. In La geografia della città di Roma e lo spazio del sacro. 
L'esempio delle trasformazioni territoriali lungo il percorso della Visita alle Sette Chiese Privilegiate, ed. C. Ceretti, 1-104. Roma: Società geografica italiana.

Susman, F. 1964. Il culto di S. Pietro a Roma dalla morte di Leone Magno a Vitaliano (461-672). Archivio della Società romana di Storia patria 84: 1-192.

Thomson, H. J. 1961 (1953). Prudentius. Volume II. London/Cambridge: William Heinemann/Cambridge University Press.

Trout, D. 2012. Inscribing Identity: The Latin Epigraphic Habit in Late Antiquity. In A Companion to Late Antiquity, ed. P. Rousseau, 170-86. Malden/Oxford: Wiley-Blackwell.

Trout, D. 2015. Damasus of Rome. The Epigraphic Poetry. Introduction, Texts, Translations, and Commentary. Oxford: Oxford University Press.

Ubl, H. 1976. Pilleus Pannonicus, die Feldmütze des spätrömischen Heeres. In Festschrift für Richard Pittioni zum siebzigsten Geburtstag. II Industriearchäologie und Metalltechnologie. Römerzeit, Frühgeschichte und Mittelalter. Sonstiges, ed. H. Mitscha-Märheim, H. Friesinger \& H. Kerchler, 214-41. Wien/Horn: Franz Deuticke/Ferdinand Berfer und Söhne OHG.

Verrando, G. N. 1981. Note di topografia martiriale della via Aurelia. Rivista di Archeologia Cristiana 57(1-2): 255-82.

Wirbelauer, E. 1994. Die Nachfolgerbestimmung im römischen Bistum (3.-6. Jh.). Doppelwahlen und Absetzungen in ihrer herrschaftssoziologischen Bedeutung. Klio 76: 388-437.

Wolter, M. 2015. Petrus I (Gestalt). In Reallexikon für Antike und Christentum, ed. G. Schöllgen, H. Brakmann, S. De Blaauw, T. Fuhrer, H. Leppin, W. Löhr, H.-G. Nesselrath and I. Tanaseanu-Döbler, 387-99. Stuttgart: Anton Hiersemann.

Wortley, J. 2004. The Legend of Constantine the Relic-Provider. In Daimonopylai. Essays in Classics and the Classical Tradition Presented to Edmund G. Berry, ed. R. B. Egan \& M. A. Joyal, 487-96. Winnipeg (Manitoba): University of Manitoba Centre for Hellenic Civilization.

Zimmermann, N. and T. Michalsky. 2017. Die Päpste und Rom zwischen Spätantike und Mittelalter. Formen der päpstlichen Machtentfaltung. Regensburg: Schnell \& Steiner.

Zwierlein, O. $2010^{2}$. Petrus in Rom. Die literarischen Zeugnisse. Mit einer kritischen Edition der Martyrien des Petrus und Paulus auf neuer handschriftlicher Grundlage. Berlin/New York: De Gruyter.

Zwierlein, O. 2013. Petrus und Paulus in Jerusalem und Rom: vom Neuen Testament zu den apokryphen Apostelakten. Berlin: De Gruyter. 